Валерія ШТЕФЮК

\title{
ВПЛИВ ВИКЛАДАЧА НА РОЗВИТОК ТВОРЧОЇ АКТИВНОСТІ СТУДЕНТІВ
}

Стаття присвячена деяким аспектам впливу особистості педагога на формування $і$ розвиток творчої активності студентів. Досліджено питання творчої компоненти як студента, так $і$ викладача. У статті представлена роль творчої активності викладача в контексті педагогічної компетентності, щз є фундаментом педагогічної майстерності. Авторкою розглянуто взаємозв'язок творчої активності викладача і креативного розвитку студента.

Ключові слова: творча активність студента, педагогічна підтримка, творча особистість, педагогічна майстерність, педагогічна компетентність, педагогічна культура.

Статья посвящена некоторым аспектам влияния личности педагога на формирование и развитие творческой активности учащихся. Исследованы вопросы творческой составляющей как студента, так и преподавателя. В статье представлена роль творческой активности преподавателя в контексте педагогической компетентности, являющейся фундаментом педагогического мастерства. Автором рассмотрена взаимосвязь творческой активности преподавателя и креативного развития студента.

Ключевые слова: творческая активность студента, педагогическая поддержка, творческая личность, педагогическое мастерство, педагогическая компетентность, педагогическая культура.

The article is devoted to some aspects of teacher's influence on the formation and development of students' creative activity. The questions of the creative component of both the student and the teacher are investigated. The article presents the place of creative activity of the teacher in the context of pedagogical competence, which is the foundation of pedagogical skill. The author examines the relationship between the creative activity of the teacher and the creative development of the student.

Key words: student's creative activity, pedagogical support, creative personality, pedagogical skills, pedagogical competence, pedagogical culture.

Метою статті є визначення є значимості професії педагога та його якісні характеристики; здійснено спробу намалювати «портрет», задати модель ідеального викладача, який виховуватиме студента нового покоління.

Методологія дослідження полягає у застосуванні аналітичного, структурного, функціонального методів дослідження особистості викладача як носія професійних і загальнокультурних компетенцій.

Наукова новизна дослідження полягає в диференціації підходів про визначення педагога як особистості, кожна 3 яких має право на існування й одночасно потребує доповнення іншою, у прагненні до ідеалу викладач має синтезувати низку властивостей.
Висновки: сучасна педагогіка вимагає модернізації світогляду викладача, у наповненні його гуманістичними ідеалами нам бачиться ключ до успіхів в системі вищої освіти, до, як вже було зазначено вище, формування і розвитку творчої активності студентів.

Ключові слова: викладач, студент, особистість, компетенції.

Однією з педагогічних умов залучення студента до навчальної діяльності є організація процесу навчання на принципах активності, спрямованої на розвиток у нього творчого начала. Тому такою важливою $є$ педагогічна підтримка студента, що включає в себе, зокрема, «допомогу у подоланні перешкод у творчій діяльності» [3, 103]. Розвиткові творчої активності може сприяти різ- 
номанітна діяльність студента при створенні необхідних умов для зміни видів діяльності.

Саме це допомагає студентові у виробленні власних творчих ідей, для реалізації яких важливо усвідомлювати їх новизну й унікальність. Зауважимо, що до числа головних мотивацій у професійній діяльності входить «можливість виконання професійних завдань 3 елементами творчості» $[4,117]$.

Творчу особистість студента характеризує його активність, що виражається в прагненні до розширення поля своєї діяльності та має деяку спрямованість, котра відображає систему мотивів й інтересів. Активність виступає залежною змінною від спрямованості, яка, в свою чергу, формується під впливом викладача.

Говорячи про активність студента, слід розуміти, що їі розвиток неможливий без активності самого викладача $[1,124]$. У цьому сенсі важливим моментом $є$ оволодіння викладачем хоча б деякими аспектами психологічної культури, що в результаті сприятиме зростанню педагогічної майстерності, основою якої виступає педагогічна творчість.

Педагогічну майстерність можна розглядати 3 різних точок зору. 3 одного боку, це найвищий рівень професійної діяльності педагога, з іншого успішне творче вирішення найрізноманітніших завдань, що стоять перед викладачем. Тобто загалом можливо сформулювати визначення педагогічної майстерності як відображення особистості педагога, його особливостей і перспектив, здатності займатися педагогічною діяльністю самостійно, $з$ творчим підходом, на кваліфікованому рівні і $з$ досягненням результату. Як бачимо, творчість у діяльності педагога посідає особливе місце. До того ж серед компонентів успішності педагога особлива увага зосереджується саме на ентузіазмові, творчій активності.

Невід'ємною частиною педагогічної майстерності є професійна компетентність педагога, однією зі складників якої виступає мотивація студента на досягнення поставлених цілей і завдань, котрі зумовлюють досягнення бажаних результатів. Іншим складником $€$ вибудовування занять на принципово новому рівні.

Педагог, маючи знання з психологічної культури, розуміє, що в умовах формування творчої особистості в процесі навчання студент повинен виробити у себе, по-перше, позитивне ставлення до самого процесу креативу, по-друге, активізувати прагнення до самовдосконалення.

У цьому разі перед самим викладачем стоїть вельми нелегке завдання, що полягає у виборі й аналізі ефективних методів і засобів для формування творчих задатків студента і подальшої реалізації його творчих пошуків, а також у перевірці результатів і коригуванні власних дій [2].

Слід акцентувати, що відсутність педагогічної творчості не може сприяти розвиткові творчого потенціалу студента. Адже творчість викладача полягає у «створенні нових способів впливу на піддослідних», до числа яких входять і композиційна частина поданого матеріалу, i організація різних видів діяльності, і новизна форм та методів навчання, а також здатність вирішувати педагогічні завдання $[2,45]$. Не варто забувати і про те, що метою і водночас результатом освіти слугує розвиток особистості студента.

Творчість викладача в його професіональній діяльності проявляється:

- в оволодінні новими знаннями в межах своєї компетентності;

- у використанні нових методів і форм навчання;

- в розробці навчально-методичного комплексу з курсу, що викладається;

- у постійному самовдосконаленні - не лише професіональному, а й особистому;

- в систематичному підвищенні рівня кваліфікації;

- в участі у конференціях різного рівня, котрі стосуються як педагогічного профілю, так і профілю дисципліни викладання;

- в організації професійних гуртків та гуртків розвитку творчого потенціалу студента;

- в участі у наукових та професійних спільнотах;

- в публікації своїх наукових праць;

- в самому бажанні вдосконалюватися.

Отже для того щоб успішно займатися творчим розвитком студента, викладачеві потрібно передусім розвиватися та вдосконалюватися самому, адже якщо студент постійно захоплений предметом, який вивчає, то він і здатен творити. Також педагог повинен розуміти, що світ культури, який відкривається студентові крізь призму навчальних курсів, вимагає від нього напруги розуму, спеціальної душевної праці. Відбувається «перехід» від світу «зовнішньої культури» до світу його «внутрішньої», власної культури.

Сам викладач, будучи творчою особистістю, має можливість реалізувати навчально-виховні цілі не лише через себе, а й через особистість іншого, звертаючись до історії науки, до історії своєї країни і світової історії. Педагогіці добре відома виховна сила прикладу. Психологічною основою 
цієї дії є схильність молоді до наслідування. За образним висловом К. Д. Ушинського, приклад - це «плідний промінь сонця для молодої душі, який нічим замінити неможливо» $[6,532]$.

У свідомості багатьох людей ще живе образ «народного учителя» початку XX століття, наділеного багатьма чеснотами. Саме тими, на які звертали увагу ще античні мислителі в межах пайдейї. Сьогодні ж ситуація така, що, з одного боку, професія педагога стала масовою, з іншого - немає наукових основ відбору молоді в «учительство». Однак у цій соціальній сфері має виховуватися особливо відповідальна еліта, здатна виконувати важливі державні та культурні завдання, тому що смисл життя і діяльності педагога пов'язаний 3 буттям самої держави, котра не має майбутнього поза молоддю. Професійно-педагогічна еліта повинна надавати соціокультурні та моральні зразки для всіх інших спільнот. При цьому навчальний заклад - це не фірма 3 надання освітніх послуг, а культурно-освітній центр.

У пошуках визначення базових характеристик особистості вчителя в філософсько-педагогічній літературі називають поняття «педагогічна майстерність», «педагогічні здібності», «педагогічний потенціал». Розкриваючи зміст останнього, називають такі потенціали, як кваліфікаційний (професійні знання і вміння); психофізіологічний (працездатність і організація своєї педагогічної праці); освітній (інтелектуальні здібності); творчий (здатність побачити нове, створити нове на ниві освіти); комунікативний (здатність до співпраці та взаємодії); моральний (ціннісно-мотиваційні здібності). В єдності ці потенціали утворюють систему, де інтегруючим, синтезуючим елементом $є$ гуманістична спрямованість особистості викладача.

Аналізуючи поняття «педагогічна майстерність», важливо відзначити, що якість підготовки педагога прямо залежна від майстерності професорсько-викладацького складу, від реальної оцінки і управління цим «віртуальним капіталом» керівництвом вищого навчального закладу. Останне дає можливість зробити правильну розстановку кадрів, домогтися високої ефективності праці педагога, здійснити розумне переміщення по «службових сходах», відпрацювати механізми підвищення кваліфікації, визначити заходи стимулювання та заохочення вчителів тощо.

Оцінка педагогічної майстерності важлива і самому викладачеві для орієнтації в своїй роботі, прийняття розумних рішень, формування і вдосконалення своїх особистісних якостей. Якщо педагог відчуває, що його майстерність отримує неадекватну оцінку, то це рано чи пізно призводить до конфліктів, до почуття тривожності, невизначеності. Наслідком цього стає зниження ефективності педагогічної праці або навіть догляд педагога в іншу сферу діяльності.

Які показники слід виділити, щоб дати об'єктивну оцінку педагогічній майстерності?

По-перше, внесок педагога в зміст його курсів, розробку підручників, навчальних посібників, нових технологій навчання і виховання, створення дидактичного матеріалу предметів, які він викладає.

По-друге, відповідність наукової кваліфікації результатам його наукової діяльності.

По-третє, рівень лекторської майстерності педагога. Історія науки знає безліч прикладів, коли блискучий вчений виявлявся посереднім педагогом: не володів відповідною методикою, йому не вистачало переконливості, емоційності та натхнення, виклад матеріалу виявлявся важкодоступним для розуміння студентами.

У вітчизняній педагогіці вимоги до викладача вузу включають такі функції, як дослідження, проектування, конструювання, організачія, комунікація.

Досліднищька функиія націлює педагога на творчість, уміння отримувати нові знання з різних джерел, удосконалювати навички логічного мислення, ставити нові педагогічні завдання.

Функиія проектування безпосередньо пов'язана 3 попередньою. Вона передбачає наявність навичок планування педагогічної діяльності, вміння знайти методи вирішення освітніх завдань.

Конструктивна функиія виражається в умінні здійснювати відбір навчально-виховної інформації, створювати нові педагогічні технології, контролювати ступінь засвоєння навчальних дисциплін молоддю.

Організаторська функиія передбачає наявність навичок управління психічним станом студента, коригувати та прогнозувати його пізнавальні можливості.

Комунікативна функиія націлює педагога на суворе, але доброзичливе, довірливе ставлення до студентів, а також на створення єдиного морального і психологічного простору в освітньо-виховному процесі.

Педагогічна практика показує, що 3 неї відходять у минуле авторитарні стосунки, вона дедалі більше насичується взаємодоповнюючими елементами в системі «викладач-студент». Трапляється і так, що деякі студенти функціональ- 
но більш грамотні, ніж їх педагоги, наприклад, швидше орієнтуються в мінливих комп'ютерних програмах та інших інформаційних даних. Досвідченим викладачам, обтяженим багатовіковим вантажем традицій, буває зовсім непросто «увійти» в нові навчальні технології. I роль «тренера» постійно змінюється: від досвідченого педагога, що володіє науковими істинами, до студента, який володіє комп'ютером і відповідними технологіями. Але це і $є$ одним із проявів принципу додатковості в сфері освіти.

Змістовна любов до педагогічної праці, прагнення передати молоді знання і вміння, побачити iii успіхи та радіти їм $€$ величинами змінними, історично мінливими. Але як такі вони були в усі часи і в усіх освітніх установах, а у викладача завжди виявлялися в єдності трьох своїх складових: індивідуальних рис характеру; індивідуальних психічних станів та соціально-значущих властивостей педагога.

В уже згаданій системі «викладач-студент», де суб'єкт-суб'єктні відносини можуть змінювати свій напрямок, взаємно передбачати і доповнювати один одного, важливою $є$ психологічна орієнтація педагога, він сам як психічний тип. У філософсько-педагогічній літературі називаються три таких типи: проактивний, реактивний, надактивний.

Проактивний викладач - ініціативний, комунікабельний, завжди в пошуках нового i, головне, знає, чого хоче і що шукає. У нього «чіткий порядок і сильна рука».

Реактивний викладач теж динамічний в своїх установках і пошуках, але вони не мають суворого, однозначного характеру. Його цілі дещо аморфні, а сам він часто пристосовується, підлаштовується до студгрупи.

Надактивний викладач схильний часто перебільшувати або абсолютизувати схильності та стихійні, неусвідомлені прояви дій студентів (активний енергійний студент у очах такого викладача - хуліган, а пасивний, інертний - ледар). Ним створюється якась нереальна, умоглядна модель студента.

Як у західно-, так і в східноєвропейських країнах до XIX століття зміцнилося розуміння того, що хороший учений не завжди хороший педагог. Педагогічні та наукові знання у викладача вищого навчального закладу часто не утворюють єдності. Тому в другій половині XX століття важливе місце в підготовці викладачів посіли такі дисципліни, як історія педагогіки, філософія освіти, соціологія освіти, педагогічна психологія та інші, що сприяло підвищенню рівня методологічної культури. Практика сьогодення демонструє, що методологічна і методична підготовка викладачів взаємно доповнюють одна одну. Нам видається, що головний методологічний принцип, який лежить в основі функціонування і розвитку системи професійно-педагогічної підготовки та підвищення кваліфікації викладачів має відображати систему тих змін, які відбуваються в науці, техніці, мистецтві, педагогічних технологіях, а також в діяльності самого викладача.

На початку XX століття педагог і філософ С. І. Гессен (1866-1943) чітко висловив стратегію і тактику викладача: «Завдання університетського викладача не в тому, щоб учити, а в тому, щоб працювати в своїй науці, якої він може вчити лише в міру своєї дослідницької роботи. Він не «викладає» свій предмет, а висловлює публічно свої наукові погляди, тому він і називається професором. Учень не просто вчиться, він займається наукою, він - studiosus. Обидва вони, за прекрасним німецьким висловом, treiben Wissenschaft, тобто рухають вперед науку. Навчання і дослідження тут збігаються, і це рівною мірою стосується як студентів, які через навчання беруться в університеті до самостійного дослідження, так і професорів, які через дослідження продовжують своє навчання, що ніколи не закінчується» $[7,310]$.

Важливою стороною діяльності педагога $€$ контроль знань. I немає сумніву в тому, що, здійснюючи контроль знань, викладач перевіряє й себе, своє вміння передати доступно інформацію. Разом з тим він чітко повинен усвідомлювати, щзо перевіряс. А перевіряти він може: базові знання; поверхневі знання (часто саме вони перевіряються стандартними тестами); загальні знання (3 широкого кола тем); глобальні знання (всесвітня «культурна грамотність»); особисті знання (вони демонструються особистими досягненнями студентів з тих чи інших предметів); спеціальні знання (вони виражаються в поглиблених знаннях 3 навчального предмета, інтересі до нього) $[8,570]$.

Виходячи з того, що ідеальним об'єктом у педагогіці є єдність минулого, теперішнього і майбутнього, що він містить в собі соціокультурний компонент, та що історико-педагогічні й філософсько-педагогічні дослідження показали значимість професії педагога і його якісні характеристики, можна спробувати намалювати «портрет», задати модель ідеального викладача.

Ідеальний викладач - це людина, яка має значний професійний досвід; досконало знає свій предмет і методику його викладання; має високий 
рівень методологічної культури; займається самоосвітою; справедлива і рівна у спілкуванні з усіма студентами, емпатична; знає правильний вихід 3 будь-якої педагогічної ситуації і може подолати будь-яку складність як у навчанні, так і у вихованні студентів.

Ми виходимо з того, що «ідеал» - це зразок, щось досконале, мета тощо. Те, до чого повинен прагнути кожен педагог. Це його проекція в майбутнє. Ідеали - це не утопія, а цінності, побачені досконало, потужні регулятиви навчально-виховного процесу.

XXI століття несе новий планетарний світогляд. Він потребує спеціальної програми перепідготовки педагогів. У модернізації світогляду викладача, у наповненні його гуманістичними ідеалами нам бачиться ключ до успіхів в системі вищої освіти, до, як вже було зазначено вище, формування і розвитку творчої активності студентів.

\section{Джерела та література:}

1. Шабанова Ю. О., Осипов А. О. Сутність і принципи гуманної педагогіки вищої школи / Ю. О. Шабанова, А. О. Осипов // Вісник Університету імені Альфреда Нобеля. Серія «Педагогіка і психологія». Педагогічні науки. 2014. - No 2 (8). - C. 123-130.

2. Амбарцумова Ж. С., Евдокимова О.В. Психологическая культура преподавателя как важный фактор формирования успешности личности студента / Ж. С. Амбарцумова, О. В. Евдокимова // Личность-слово-социум : материалы VI Междунар. науч.-практ. конф. - Белорусский государственный экономический университет, 2006 [Электронный ресурс]. - Режим доступа: http://pws-conf.ru/ nauchnaya/lss-2006/371-formirovanie-lichnosti-v-sociume/8175-psihologicheskaya-kultura-prepodavatelya-kak-vajnyyfaktor-formirovaniya-uspeshnoy-lichnosti-studenta.html

3. Васинская И. А. Влияние личности преподавателя на развитие творческого потенциала студентов / И. А. Васинская // Профессионализация в условиях современной системы образования : сборник научных статей / Институт социально.экономического прогнозирования и моделирования ; ред. В. П. Делия-Балашина : Д-с-По, 2011. C. $44-48$.

4. Суворов В. С. Развитие творческой личности студента важнейший фактор качества образования / В. С. Суворов // Интеграция образования : научно-методический журнал. - 2003. - № 3. - С. 103-106.
5. Тихонова О. В. Пути решения проблемы адаптации молодых специалистов в банковском секторе как фактора, затрудняющего карьерный рост / О. В. Тихонова // Научные исследования : от теории к практике: материалы II Междунар. науч.-практ. конф. (12.02.2015 г.) / редкол. : О. Н. Широков [и др.]. - Чебоксары : ЦНС «Интерактив плюс», 2015. - С. 116-119.

6. Ушинский К. Д. Собрание сочинений : в 11 т. ; редкол. ; [А. М. Сголин (гл. ред) и др.]. - М.-Л. : Изд-во Акад. пед. наук РСФСР, 1948-1952. - Т. 2. Педагогические статьи (1857-1861). $-656 \mathrm{c}$.

7. Гессен С. И. Основы педагогики. Введение в прикладную философию / С. И. Гессен. - М. : Школа-Пресс, 1995. $448 \mathrm{c.}$

8. Драйден Г., Вос Дж. Революция в обучении / Гордон Драйден, Джаннетт Вос. - М. : ПАРВИНЭ, 2003. - 672 с.

\section{Referens:}

1. Shabanova, Yu. O., Osipov, A. O. (2014). Sutnist and the principle of humanistic pedagogy in schoolchildren // News to the University of Alfred Nobel. Pedagogical sciences [in Ukrainian].

2. Ambartsumova, Zh. S., Evdokimova, O. V. (2006). Psychological culture of the teacher as an important factor in the formation of the success of the student's personality.Personality-word-society: materials VI Intern. scientific-practical. Conf.- Belarusian State Economic University. - URL: http://pws-conf.ru/nauchnaya/lss2006/371-formirovanie-lichnosti-v-sociume-/8175psihologicheskaya-kultura-prepodavatelya-kak-vajnyyfaktor-formirovaniya-uspeshnoy-lichnosti

3. Vasinskaya, I. A. (2011). The influence of the teacher's personality on the development of students' creative potential. Professionalization in the conditions of the modern education system: a collection of scientific articles / Institute for Socioeconomic Forecasting and Modeling [in Ukrainian].

4. Suvorov, V. S. (2003). Development of the creative personality of the student - the most important factor of the quality of education // Integration of Education: a scientific and methodical journal [in Ukrainian].

5. Tikhonova, O. V. (2015). Ways to solve the problem of adaptation of young professionals in the banking sector as a factor hampering career «Scientific research: from theory to practice: materials II Intern. scientific-practical». Cheboksary : CNS «Interactive Plus» [in Russian].

6. Ushinsky, K. D (1948-1952). Collected works : in 11 t. - Izdvo Akad. ped. sciences of the RSFSR. T. 2, 656 [in Russian].

7. Gessen, S. I. (1995). Fundamentals of Pedagogy. Introduction to Applied Philosophy. - Moscow : «School-Press», 448 [in Russian].

8. Dryden, G., Vos, J. (2003). The Revolution in Learning. Moscow: Parvine, 672 [in Russian]. 